\title{
Predictors Of Customer Loyalty To Mobile Service Provider In South Africa
}

Richard Chinomona, Vaal University of Technology, South Africa Maxwell Sandada, Vaal University of Technology, South Africa

\begin{abstract}
In spite of the increasing research on consumer behaviour, there is a dearth of studies that have investigated the influence of mobile provider service quality in customer satisfaction regarding customer trust and loyalty in the African mobile communication context. Therefore, this study examines the relationships using a data set of 151 mobile service clients in Gauteng Province of South Africa. All the posited five hypotheses are supported. The results indicate that the relationships between mobile service quality-customer satisfaction, customer satisfactioncustomer trust, customer satisfaction-customer intimacy, customer trust-customer loyalty, and customer intimacy-customer loyalty are positive in a significant way. The research paper discusses both academic and managerial implications of the results and future research directions are suggested.
\end{abstract}

Keywords: Mobile Service Quality; Customer Satisfaction; Customer Trust; Customer Intimacy; Customer Loyalty; South Africa

\section{INTRODUCTION}

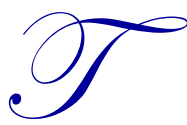

oday's dynamic and competitive business environment necessitates the need for organisations to create and maintain customer loyalty. Researchers agree that customer loyalty is beneficial because businesses reduce marketing costs, profits increase, loyal customers engage in positive word-ofmouth behaviours, and loyal customers always try new products and make useful suggestions for service improvement (Wallace, Giese \& Johson, 2004; Bushoff \& Du Plessis, 2009). Therefore, over the years, organisations have focused on achieving customer loyalty and on ascertaining the factors influencing customer loyalty (Han \& Ryu, 2009). Literature has shown that satisfying customers positively influences customer trust (Lin \& Wang, 2006) and customer loyalty (Hamadi, 2010). According to Lee (2004), customer trust is also crucial as it creates customer loyalty. Customer intimacy is also confirmed as an important factor influencing customer loyalty (Bugel, Verhoel \& Buunk, 2011). The loyalty of customers to the retailer also leads to intentions by customers to repurchase (Kang, Okamoto \& Donovan, 2004). This shows that it is the responsibility of mobile phone providers to implement service quality, customer satisfaction, trust and intimacy strategies in order to create and maintain customer loyalty.

Although previous research has examined customer service quality, satisfaction, trust, intimacy and loyalty, and the nature of their relationships that exist between them, their effect on customer loyalty still remains to be further investigated (Lai, Griffin \& Babin, 2009), particularly in the context of mobile service provision in Africa. Evidently, a cross examination of the existing spate of literature indicates that research on the influence of customer mobile service quality, satisfaction, trust, and intimacy on customer loyalty to mobile service providers is scarce in the African context. More so, the majority of the studies examining these variables have been carried out in American, European, and Asian countries (e.g. Lin \& Wang, 2006; Bushoff \& Du Plessis, 2009; Bugel, Verhoel \& Buunk, 2011). Perhaps it may be ingenuous to assume a priori that the results of similar studies conducted in these developed countries are applicable to developing and emerging countries like South Africa. This study seeks to close this gap by exploring the influence of mobile service quality on customer satisfaction, trust, intimacy and, ultimately, their loyalty to mobile service providers in South Africa. 
It is the contention of this study that exploring the influence of mobile service quality on customer satisfaction, trust, intimacy, and loyalty will provide practical insights for telephone mobile operators on how to provide quality service and satisfy customers in order to gain customer trust and customer intimacy, which will ultimately lead to customer loyalty. Such insights are important because they help mobile telephone operators to be competitive. The main theoretical contribution of this research is to conceptualise and empirically demonstrate the linkages between service quality, satisfaction with the service, trust with the service provided, customer intimacy with the service, and customer loyalty.

\section{LITERATURE REVIEW}

\section{Service Quality}

Providing a high level of service quality is critical in today's competitive business environment as it may be used as a differentiation variable, hence a source of competitive advantage (Boshoff \& DuPlessis, 2009). Deng, Lu, Wei and Zhang (2010) describe service quality as the degree to which the service provider persistently and excellently provides the overall service. According to Sivados and Prewitt (2000), service quality is the standard of service delivery. Lee (2010) regards service quality as a form of consumer attitude that is formed after comparing the expectations with the actual performance provided by the service provider. Wong and Sohal (2003) identified two categories of quality service - technical and functional. The technical quality of the service refers to what is done to provide the service whereas the functional quality relates to how the service is provided. In the context of mobile phones, the main indicators of service quality are those of navigation and visual designs, management and customer services, system reliability and ease of connection (Kuo, Wu and Deng, 2009). To examine the service quality of Korean mobile telecommunications, Kim, Park and Jeong (2004) used dimensions, such as reasonability of prices, quality of mobile devices, variety and design of device types, convenience, ease of subscribing, staff friendliness, and speed of complaint processing and ease of reporting complaints. The five dimensions; namely, assurance, empathy, reliability, responsiveness and tangibles, are considered to be crucial in evaluating service provision (Boshoff \& Du Plessis, 2009).

\section{Customer Satisfaction}

Given the intense competitive business world and the increase in consumer awareness, customer satisfaction has become a crucial issue among scholars and practitioners. Therefore, in order to remain competitive and sustainable, marketers need to make sure that they satisfy their customers. It has been proven that customer satisfaction positively influences repurchase intention (Huddleston, Whipple, Mattick \& Lee, 2009), it is an important predictor of customer loyalty (Cheng, Chiu, Hu \& Chang, 2011), and it also positively impacts on customer trust (Dabholkar \& Sheng, 2012). Scholars such as Cheng et al. (2011) argue that satisfying a customer is even more important than profit-making. The authors reasoned that satisfying a customer precedes profit-making; hence, as long as customers are satisfied, the business will make a profit. Customer satisfaction has therefore become an important measure of the behaviour of consumers (Cheng et al., 2011) and a key indicator of business performance (Sandada 2013). Chang (2006) views customer satisfaction as a post consumption evaluation of a product or a service and defines it as the ability of an organisation to provide a service performance that exceeds the customer expectations. Deng, Lu, Wei and Zhang (2010) state that customer experiences cumulative satisfaction after having a good experience of using the product or service. The authors also group satisfaction into two types: 1) the transaction specific satisfaction and 2) the general satisfaction. While the former refers to satisfaction after a given service encounter, the latter describes the consumers' overall rating of the service or product based on previous experiences (Deng et al., 2010). For Hwang and Zhao (2010), customer satisfaction occurs when there is confirmation and positive disconfirmation of customer expectations. It implies that customers are satisfied when their expectations are met and when their expectations are not met but they still feel good about the performance. Choi and Sheel's (2012) definition include the output and process aspects of customer satisfaction. The output definition views customer satisfaction as a cognitive or mental state in which consumers feel that they have been adequately or inadequately compensated. Regarding the process, customer satisfaction occurs when customer experience matches or exceeds the expectations. Therefore, consumer evaluation is crucial to customer satisfaction (Choi \& Sheel, 2012). In order to satisfy consumers, retailers need to understand the motivations for shopping because customers gain satisfaction from diverse shopping aspects (Huddleston et al., 2009). Some of the 
motivations for consumer shopping mentioned by Huddleston et al. (2009) are task-oriented while others are activity-oriented and they include shopping to divert from daily routine, to learn more about trends and new products, or to enjoyment bargaining. The definitions discussed above show that customer satisfaction is an outcome of an evaluation by customers on the service provided against their expectations.

\section{Customer Trust}

Customer trust is confidence that customers have in the reliability and competence of service providers (Boshoff \& du Plessis, 2009). According to Chang (2012), customer trust consists of affective and cognitive trust. In cognitive trust, consumers are confident that the service provider is competent and reliable in keeping promises, whereas in affective trust, consumers believe that while the service providers seek to maximise profits, they also have genuine concern for customer needs. Dabholkar and Sheng (2012) believe that customers trust service providers if they believe that the product or service provides benefits to them. Customer trust influences the development of consumer commitment to the service provider because of the positive experiences they had with the product or service (Olaru, Purchase \& Peterson, 2008). This indicates that retailers need to make sure that the service encounters satisfy customers in order to ensure commitment by consumers. Echoing the same sentiments, Boshoff and du Plessis (2009) assert that customer trust is a key component of relationship building. Customer trust involves taking a certain degree of risk as customers are vulnerable to the service providers (Hong \& Cho, 2011). Therefore to gain customer trust, the retailing industry should be reliable and competent in service provision.

\section{Customer Intimacy}

In the face of competitive market conditions, businesses need to deliver consumer value by having intimate relationships with customers in order to increase their loyalty ( $\mathrm{Li}, 2009)$. Customer intimacy is the customers' emotional attachment that binds them to certain brands or service providers (Lee, Kyle \& Scott, 2012). The emotional and social ties are a result of consistent satisfying experiences of service provision (Lee \& Shen, 2013). According to Pontiskoski and Asakawa (2009), businesses using customer intimacy strategy are customer centric and their day-to-day operations are dictated by customer needs. Such organisations need to carefully study and understand the specific needs of customers so that they can tailor-make the products to customer specifications (Reimann, Schilke \& Thomas, 2010). Liang, Li and Turban (2009) have observed that customer intimacy is summarised in $5 \mathrm{Cs}$ - communication, caring, commitment, comfort, and conflict resolution. In the same vein, $\mathrm{Li}$ (2009) identified the two ways; namely, customisation and brand loyalty, that businesses may use to build customer intimacy. Customisation involves providing customised products and services, customised production delivery times and prices, and frequent one-on-one dialogue with customers. Brand loyalty stems from providing reliable brands to help reduce perceived customer risk and increase confidence in the brand ( $\mathrm{Li}, 2009)$. For organisations to create and sustain customer intimacy, Beatty, Huselid and Schneier (2003) proposed conditions that include constantly finding and improving solutions to customer needs, satisfying and anticipating customer needs and employing employees who constantly seek customer intelligence and share information with co-workers.

\section{Customer Loyalty}

Due to intense competition in the market place, businesses have increased efforts to implement the customer retention strategy in order to maximise the lifetime value of customers (Boshoff \& du Plessis, 2009). According to Deng, Lu, Wei, Zhang (2010), customer loyalty refers to commitment by customers to make consistent repeat purchases of a preferred brand or service in spite of situational and marketing efforts to influence switching behaviour. For Cheng et al. (2011), customer satisfaction means creating and maintaining long-term relationships with customers. Hong and Cho (2011) assert that customer loyalty indicates the consumers' psychological attachment to the product as well as attitudinal advocacy toward the business. Through strengthened customer loyalty, businesses are able to retain customers and, consequently, profits increase (Lee, 2010). This complies with a suggestion by Deng et al. (2010) who pointed out that customer loyalty is a predictor of long-term viability of the firm as loyal customers are not influenced by bad publicity and they provide free word-of-mouth advertising and referrals. Cheng et al. (2011) proposed that it is cost-effective to maintain existing customers than obtaining new ones. To this the authors proceeded to state that the cost of developing a new customer is between five and nine times the cost of maintaining existing customers. This demonstrates that retailers need to retain loyal customers 
because, through cost-effectiveness, there are high chances of survival and strong future growth. According to Boshoff and du Plessis (2009), the benefits of customer loyalty are that loyal customers are cheap to maintain, are price insensitive, spread free positive word-of-mouth, always provide suggestions, and always try new products.

\section{CONCEPTUAL FRAMEWORK AND HYPOTHESIS}

Drawing from the extant literature from services marketing, a conceptual model is developed in Figure 1. The model consists of five constructs; that is, one predictor - mobile service provider's service quality, three mediators - customer's trust in the mobile phone, customer's satisfaction with mobile service and customer's intimacy with mobile service provider and an outcome variable - customer loyalty to mobile service. Conceivably, the mobile provider's service quality influences customer satisfaction and then customer satisfaction triggers both customer intimacy and customer trust and consequently customer satisfaction and customer intimacy influence customer loyalty to the mobile service. Detailed explanations of the associations between these constructs are provided in the hypotheses developed hereafter.

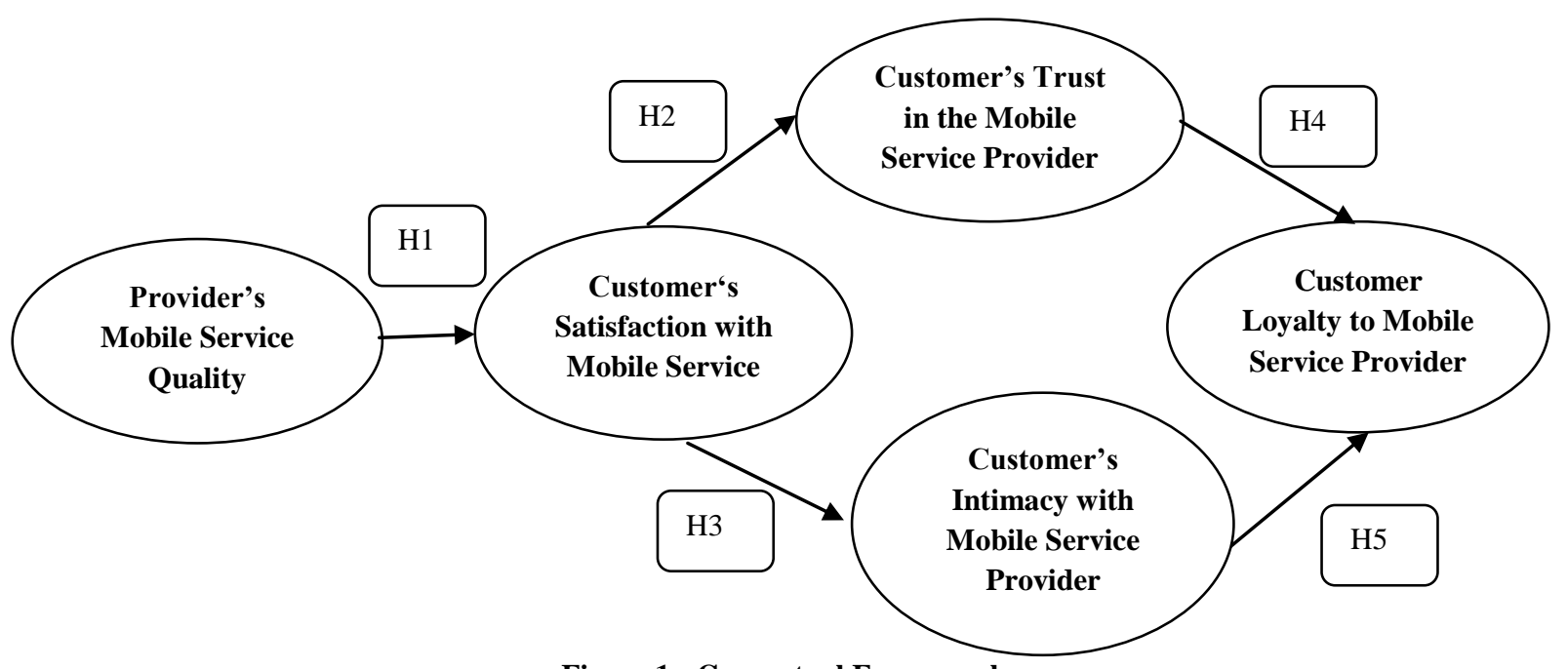

Figure 1: Conceptual Framework

\section{Service Quality and Customer Satisfaction}

Three theories exist to explain the relationship between service quality and customer satisfaction: 1) customer satisfaction is a predictor of quality of service, 2) service quality is an antecedent of customer satisfaction, and 3) that the relationship is reciprocal (Deng et al., 2010). However, several studies support the view that service quality is a predictor of customer satisfaction (Sivadas \& Prewitts, 2000; Kuo, Wu, \& Deng, 2009; Siddiqi, 2011). Katibi, Ismail and Thyagarajan (2002) found the four service quality dimensions that are predictors of customer satisfaction included understanding business needs, operating hours, fault reporting centre, and response times. Similarly, a study of retail banking in Bangladesh by Siddiqi (2011) reported that service quality attributes, such as reliability, responsiveness, assurance, empathy, and tangibility, all had a positive influence on customer satisfaction. In the telecommunications context, Kuo et al. (2009) also confirmed service quality as a predictor of customer satisfaction. Lee (2010) studied the factors that influence customer loyalty of Korea's mobile services sector and found also that service quality was a significant antecedent of customer satisfaction. Furthermore, an investigation of patients' satisfaction of medical centres in Taiwan by Hu, Chiu, Cheng and Hsieh (2010) revealed that the medical centre's service attributes - namely, service technology, product reliability and product customisation - had a positive influence on customer satisfaction because of fulfilment of patient expectations. The other authors who endorse the view that service quality is a predictor of customer satisfaction are Beerli, Martin and Quintana (2004) and Kim et al. (2004). Based on these findings, the study therefore proposed that:

H1: High levels of service quality provided by the mobile service provider positively influence customer's satisfaction. 


\section{Customer Satisfaction and Customer Trust}

Literature shows bi-directional relationships between satisfaction and trust. The reason is that no general consensus among scholars exists as to which, between these variables, is a dependent and independent variable. For example, Lin and Wang (2006) and Chang (2012) propose that trust precedes satisfaction. What it means is customers trust the service providers probably based on their image rather than experience. This study argues that customers first deal with the business and evaluate it based on those experiences. If the experiences meet their expectations, then they become satisfied and will later on trust the business. Therefore, this study considers satisfaction as the predictor of trust. This argument was supported by Dabholkar and Sheng (2012) who tested the effect of satisfaction on trust with the context of online business transactions. The implication is that due to satisfying experiences with the business, customers begin to have trusting beliefs about the service provider (Dabholkar \& Sheng, 2012). The influence of customer satisfaction on customer trust has also been confirmed by a study by Ou and Sin (2003) who recommended that in order to strengthen customer trust of internet customers, eretailers need to first satisfy internet shoppers on privacy and security issues. This demonstrates the effect of satisfaction on trust. Similarly, Olaru et al. (2008) assert that the positive experiences that customers have lead to satisfaction and the satisfying experiences consequently result in customer trust. The assertion by Boshoff and du Plessis (2009) - that trust is crucial in relationships - means that customers need to have prior pleasing experiences leading to satisfaction and will eventually develop trust with the service provider. In light of this, the study postulated that:

H2: Customers satisfaction with the quality of mobile service positively influences their trust in the mobile service provider.

\section{Customer Satisfaction and Customer Intimacy}

Customers who are satisfied by the service provision develop intimate relationships with service providers (Li, 2009). Lee et al. (2012) studied the effect of customer satisfaction on place attachment and found that satisfied customers develop emotional attachment to the service provider. Liang et al. (2009) argue that the customers who are satisfied due to constant communication and caring by the service provider lead to are motivated to commit themselves to long term close relationships with these service providers. The authors reasoned that once satisfied, customers begin to have confidence and perceive low risk as a result of such ties. This corroborates with Li (2009) who asserted that customer satisfaction leads to customer intimacy because they believe that their needs will continuously be satisfied. Based on the foregoing discussion, the study developed the following hypothesis:

H3: Customers' satisfaction with mobile phone service positively influences customers' intimacy with the mobile phone service provider.

\section{Customer Trust and Customer Loyalty}

When customers trust the service provider, they are likely to be loyal toward the service provider (Deng et al. 2010). According to Hong and Cho (2011), the trustworthiness of a business plays a critical role in creating and maintaining customer loyalty. The study of Bansal et al. (2004) showed that there is a significant positive relationship between customer trust and loyalty. The results are compatible with those of other studies by Yee (2004) and Lin and Wang (2006). Avramakis (2011) studied the customer relationships in the Swiss Financial system and reported that customer trust positively predicts customer loyalty. This positive relationship was also substantiated by Sirdeshmurk, Sigh and Sabel (2012) who developed a framework of understanding customer trust and loyalty relationship in the airline and retailing industry. The results of the study indicate that trustworthy behaviour by consumers directly influences trust. The authors argued that when the service providers manage to build customer trust, customers do perceive low risk and will have more confidence in the service provider's reliability and integrity and as a result become loyal. Deng et al. (2010) argues that achieving a customer trust is the main contributor to customer loyalty. Therefore, this study proposes that:

H4. Customers' trust in the mobile service provider positively influences their loyalty to the mobile service provider. 


\section{Customer Intimacy and Customer Loyalty}

According to Bugel, Verhoef and Buunk (2010), customer intimacy contributes to customer loyalty because customers, especially in high involvement markets like automobiles, prefer to repurchase from the same dealers. The authors therefore recommend investment in intimate relationships. Customer intimacy organisations constantly learn from customers which leads to further customisation that results in customer loyalty (Beatty et al., 2003). This is consistent with Bugel et al. (2011) who believe that a customer's intimacy with a service provider influences customer loyalty because of the trust and commitment to long-term relationships. A study by Lee et al. (2012) presented results showing that customer's bond with a service is a significant predictor of customer loyalty. Reimann et al. (2011) found that customer intimacy enables organisations to understand customer needs. This is a demonstration that when their needs are constantly met, customers become loyal. Liang et al. (2009) asserted that due to communication, caring, comfort, commitment, and conflict resolution, customers develop intimacy with service providers and ultimately become loyal. In the same line of thinking, Li (2009) argues that customer intimacy, through customisation and brand loyalty, enhances customer loyalty as customers have confidence in the service quality. Thus, the study argues that:

H5: Customers' intimacy with the mobile phone service provider positively influences their loyalty to the mobile phone service provider.

\section{RESEARCH METHODOLOGY}

\section{Sample and Data Collection}

The target population for the study was South African mobile service customers or clients in Gauteng who utilised the MTN, Vodacom, Cell C, and Telkom mobile service providers. Students from the Vaal University of Technology were recruited as research assistants to distribute and collect the questionnaires. Of the total of 170 questionnaires distributed, 151 were retrieved and useable for the final data analysis, representing a response rate of 89 percent. To eliminate differences in response patterns due to different reference points, all respondents were prompted to answer the questionnaire with reference to their mobile service provider. Respondents were then asked to indicate their mobile service provider and then complete the entire questionnaire, guided by the research assistants.

\section{Measurement Instrument and Questionnaire Design}

Research scales were operationalised on the basis of previous work. Proper modifications were made in order to fit the current research context and purpose. "Mobile service quality" measure used a four-item scale while "Customer satisfaction" used a five-item scale all adapted from Ayden \& Ozer (2005) and Shemwell, Yavas \& Bilgin (1998), respectively. "Customer trust" used a three-item scale measure and "Customer intimacy" was measured using a three-item scale, all adapted from Liua, Guo \& Lee (2011). Finally, "Customer loyalty" was measured using a three-item scale adapted from Deng, Lu, Wei \& Zhang (2010). All the measurement items were measured on a five-point Likert-type scale that was anchored by $1=$ strongly disagree to $5=$ strongly agree to express the degree of agreement. Individual scale items are listed in the Appendix.

\section{Respondent Profile}

Table 1 presents the description of the participants. The respondents were asked to report their demographic information, including gender, age, marital status and education. The respondents were predominantly females (57.6\%); the median age group of the respondent was that of less than 30 years $(54.3 \%)$; MTN and Vodacom mobile service occupy more than half of the respondents $(62.3 \%)$, and $57 \%$ of the respondents were single. About $71 \%$ of the respondents had either high school (43.7\%) or university level of education (27.2\%), and the remainder had primary school (19.9) or postgraduate level of education $(0.09 \%)$. 
Table 1: Sample Demographic Characteristics

\begin{tabular}{|c|c|c|}
\hline Gender & Frequency & Percentage \\
\hline Male & 64 & $42.4 \%$ \\
\hline Female & 87 & $57.6 \%$ \\
\hline Total & 151 & $100 \%$ \\
\hline Age & Frequency & Percentage \\
\hline$\leqq 30$ & 82 & $54.3 \%$ \\
\hline $31-60$ & 51 & $33.8 \%$ \\
\hline$\geqq 60$ & 18 & $11.9 \%$ \\
\hline Total & 151 & $100 \%$ \\
\hline Mobile Service Provider & Frequency & Percentage \\
\hline MTN & 53 & $35.1 \%$ \\
\hline Vodacom & 41 & $27.2 \%$ \\
\hline Cell C & 31 & $20.5 \%$ \\
\hline 8 ta & 26 & $17.2 \%$ \\
\hline Total & 151 & $100 \%$ \\
\hline Marital Status & Frequency & Percentage \\
\hline Married & 65 & $43.0 \%$ \\
\hline Single & 86 & $57.0 \%$ \\
\hline Total & 151 & $100 \%$ \\
\hline $\begin{array}{l}\text { Level of Education } \\
\end{array}$ & Frequency & Percentage \\
\hline Primary School & 30 & $19.9 \%$ \\
\hline High School & 66 & $43,7 \%$ \\
\hline University & 41 & $27.2 \%$ \\
\hline Postgraduate & 14 & $0.09 \%$ \\
\hline Total & 151 & $100 \%$ \\
\hline
\end{tabular}

\section{DATA ANALYSIS}

\section{Structural Equation Modelling Approach}

In order to statistically analyze the measurement and structural models, this study used Smart PLS software for the Structural Equation Modeling (SEM) technique (Ringle, Wende \& Will 2005). In SEM, the measurement model refers to the linkages between the latent variables and their manifest variables, and the structural model captures the hypothesized causal relationships among the research constructs (Chin \& Newsted, 1999). Unlike AMOS and LISREL, which are covariance-based approaches, Smart PLS is a regression-based technique that originates from path analysis. Smart PLS has emerged as a powerful approach to study causal models involving multiple constructs with multiple indicators (Chinomona \& Surujal, 2012). Smart PLS - a component-based method - has an ability to model latent constructs that are uncontaminated by measurement error under conditions of nonnormality. It has the ability to handle complex predictive models in small-to-medium sample sizes. Since the current study sample size is relatively small (150), Smart PLS was found more appropriate and befitting the purpose of the current study. In this respect, the Bootstrapping resampling method was used to test the statistical significance of the relationships. This procedure entailed generating 200 sub-samples of cases randomly selected, with replacement, from the original data. Table 2 presents evidence on the reliability and validity of the measurement model.

\section{Measurement Model}

To ensure convergent validity, the researcher checked if items loaded on their respective (a priori) constructs with loadings greater than 0.6. Furthermore, discriminant validity was checked by ensuring that there was no significant inter-research variables cross-loadings (Chin, 1998). As can be seen in Table 2, all items have loadings greater than 0.6 (i.e., ranging from 0.677 to 0.876 ), with no cross-loadings greater than 0.898 , while tstatistics derived from bootstrapping (200 resamples) suggest all loadings are significant at pb0.001. As such, this confirms that all the measurement items converged well on their respective constructs and therefore are acceptable measures. 
Table 2: Accuracy Analysis Statistics

\begin{tabular}{|c|c|c|c|c|c|c|c|c|}
\hline \multicolumn{2}{|c|}{ Research Construct } & $\begin{array}{c}\text { LV Index } \\
\text { Value }\end{array}$ & $\begin{array}{l}\text { R-Squared } \\
\text { Value }\end{array}$ & $\begin{array}{c}\text { Cronbach's } \\
\alpha \text { value }\end{array}$ & $\begin{array}{l}\text { C.R. } \\
\text { Value }\end{array}$ & AVE Value & Communality & $\begin{array}{c}\text { Factor } \\
\text { Loading }\end{array}$ \\
\hline \multirow{4}{*}{ SQ } & SQ1 & \multirow{4}{*}{4.349} & \multirow{4}{*}{0.000} & \multirow{4}{*}{0.845} & \multirow{4}{*}{0.896} & \multirow{4}{*}{0.683} & \multirow{4}{*}{0.683} & 0.765 \\
\hline & SQ2 & & & & & & & 0.872 \\
\hline & SQ3 & & & & & & & 0.876 \\
\hline & SQ4 & & & & & & & 0.787 \\
\hline \multirow{5}{*}{ CS } & CS1 & \multirow{5}{*}{4.337} & \multirow{5}{*}{0.653} & \multirow{5}{*}{0.846} & \multirow{5}{*}{0.891} & \multirow{5}{*}{0.623} & \multirow{5}{*}{0.623} & 0.866 \\
\hline & CS2 & & & & & & & 0.856 \\
\hline & CS3 & & & & & & & 0.836 \\
\hline & CS4 & & & & & & & 0.690 \\
\hline & CS5 & & & & & & & 0.677 \\
\hline \multirow{3}{*}{ CT } & CT1 & \multirow{3}{*}{4.425} & \multirow{3}{*}{0.459} & \multirow{3}{*}{0.830} & \multirow{3}{*}{0.898} & \multirow{3}{*}{0.747} & \multirow{3}{*}{0.747} & 0.864 \\
\hline & CT2 & & & & & & & 0.855 \\
\hline & CT3 & & & & & & & 0.873 \\
\hline \multirow{3}{*}{ CI } & CI1 & \multirow{3}{*}{4.203} & \multirow{3}{*}{0.359} & \multirow{3}{*}{0.712} & \multirow{3}{*}{0.838} & \multirow{3}{*}{0.634} & \multirow{3}{*}{0.634} & 0.694 \\
\hline & CI2 & & & & & & & 0.857 \\
\hline & CI3 & & & & & & & 0.828 \\
\hline \multirow{3}{*}{ CL } & CL1 & \multirow{3}{*}{4.164} & \multirow{3}{*}{0.442} & \multirow{3}{*}{0.760} & \multirow{3}{*}{0.862} & \multirow{3}{*}{0.676} & & 0.867 \\
\hline & CL2 & & & & & & 0.676 & 0.848 \\
\hline & CL3 & & & & & & & 0.746 \\
\hline
\end{tabular}

Note: SQ = Service Quality; CS = Customer Satisfaction; CT = Customer Trust; CI = Customer Intimacy; CL = Customer Loyalty

According to Chin (1998), research variables should have an average variance extracted (AVE) of more than 0.5 and a composite reliability of more than 0.7 (convergent validity), and inter-construct correlations should be less than the square-root of the AVE (discriminant validity). As can be seen in Table 2, all constructs exceed these criteria with AVE and CR generally equal or greater than 0.5 and 0.8 , respectively. Furthermore, as indicated in Table 3, the square-root of the lowest AVE is 0.82 and is greater than the highest inter-construct correlation value (0.0.808). All in all, these results confirm the existence of discriminant validity of the measurement used in this study.

Table 3: Correlations between Constructs

\begin{tabular}{|l|c|c|c|c|c|}
\hline \multicolumn{1}{|c|}{ Research Constructs } & SQ & CS & CT & CI & CL \\
\hline Service Quality (SQ) & 1.000 & & & & \\
\hline Customer Satisfaction (CS) & 0.808 & 1.000 & & & \\
\hline Customer Trust (CT) & 0.468 & 0.677 & 1.000 & & \\
\hline Customer Intimacy (CI) & 0.553 & 0.599 & 0.553 & 1.000 & \\
\hline Customer Loyalty (CL) & 0.410 & 0.566 & 0.636 & 0.513 & 1.000 \\
\hline
\end{tabular}

Note: $\mathrm{SQ}=$ Service Quality; CS = Customer Satisfaction; CT = Customer Trust; CI = Customer Intimacy; CL = Customer Loyalty

\section{Path Model}

PLS also generates the path coefficients for the relationships modelled among the constructs. The significance of these coefficients was assessed using the bootstrap procedure (with 200 sub-samples) that provided the t-values for each path estimate. Figure 2 and Table 4 present the results of the PLS analysis on the structural model along with the path estimates and t-values. Support for the study hypotheses, which are labelled on their corresponding paths in Figure 2, could be ascertained by examining the directionality (positive or negative) of the path coefficients and the significance of the t-values. The standardized path coefficients are expected to be at least 0.2 and preferably greater than 0.3 (Chin 1998). 


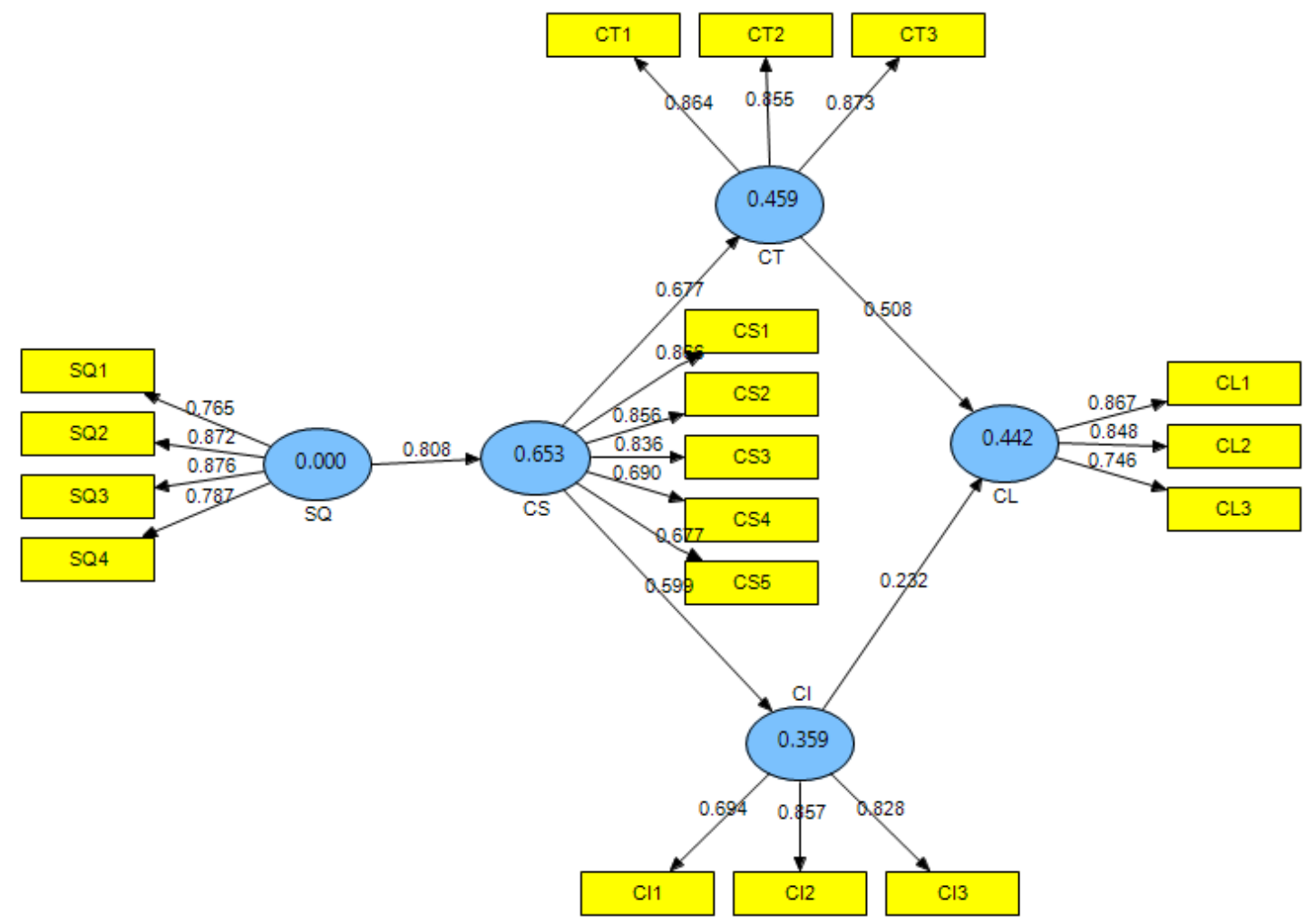

Figure 2: Measurement and Structural Model Results Note: $\mathrm{SQ}=$ Service Quality; $\mathrm{CS}=$ Customer Satisfaction; $\mathrm{CT}=$ Customer Trust;

$\mathrm{CI}=$ Customer Intimacy; $\mathrm{CL}=$ Customer Loyalty

The results provide support for the proposed positive relationships between the five relationships (i.e., H1, H2, H3, H4 and H5). Figure 2 and Table 4 provide the path coefficients for H1, H2, H3, H4 and H5 (i.e., 0.808, $0.677,0.599,0.508$ and 0.392 , respectively).

Table 4: Results of Structural Equation Model Analysis

\begin{tabular}{|l|c|c|c|c|}
\hline \multicolumn{1}{|c|}{ Proposed Hypothesis Relationship } & Hypothesis & $\begin{array}{c}\text { Path } \\
\text { Coefficients }\end{array}$ & $\begin{array}{c}\text { T- } \\
\text { Statistics }\end{array}$ & Rejected/Supported \\
\hline Service Quality (SQ) $\rightarrow$ Customer Satisfaction (CS) & H1 & 0.808 & 19.700 & Supported \\
Customer Satisfaction (CS) $\rightarrow$ Customer Trust (CT) & H2 & 0.677 & 12.292 & Supported \\
\hline Customer Satisfaction (CS) $\rightarrow$ Customer Intimacy (CI) & H3 & 0.599 & 7.702 & Supported \\
\hline Customer Trust (CT) $\rightarrow$ Customer Loyalty (CL) & H4 & 0.508 & 7.011 & Supported \\
\hline Customer Intimacy (CI) $\rightarrow$ Customer Loyalty (CL) & H5 & 0.232 & 2.392 & Supported \\
\hline
\end{tabular}

Note: $\mathrm{SQ}=$ Service Quality; CS = Customer Satisfaction; CT = Customer Trust; CI = Customer Intimacy; CL = Customer Loyalty

Overall, $\mathrm{R}^{2}$ for ERS (0.439) in Figure 2 indicates that the research model explains more than $43 \%$ of the variance in the endogenous variables. Following formulae provided by Tenenhaus, Vinzi, Chatelin \& Lauro (2005), the global goodness-of-fit $(\mathrm{GoF})$ statistic for the research model was calculated using the equation:

$\mathrm{GoF}=\sqrt{\overline{\mathrm{AVE}} * \overline{\mathrm{R}^{2}}}$

The calculated global goodness of fit $(\mathrm{GoF})$ is 0.57 , which exceeds the threshold of GoF $>0.36$ suggested by Wetzels, Odekerken-Schröder \& van Oppen (2009). Thus, this study concludes that the research model has a good overall fit. 


\section{DISCUSSION OF RESULTS}

The results in Table 4 and Figure 2 provide support for the five (5) hypotheses (H1, H2, H3, H4 and H5). Hypothesis 1 posited a positive relationship between service quality and customer satisfaction. Consistent with H1, the result in Table 4 and Figure 2 indicates that there is a significant $(t=19.700)$ positive $(\beta=0.808)$ relationship between service quality and customer satisfaction. Therefore, $\mathrm{H} 1$ is supported.

Hypothesis 2 posited a positive association between customer satisfaction and customer trust. Hypothesis 2 , results indicated that customer satisfaction is positively associated with customer trust $(\beta=0.677)$ and the relationship is significant $(\mathrm{t}=12.292)$. This is consistent with the prediction of $\mathrm{H} 2$ and is therefore supported. The standardized coefficient and significant levels of customer satisfaction $(\beta=0.599 ; \mathrm{t}=7.702)$ is positive and significant. This is consistent with the prediction of $\mathrm{H} 3$ and is supported. Thus, a higher level of customer satisfaction is associated with higher levels of customer intimacy. Furthermore, the results in Table 4 and Figure 2, are in line with $\mathrm{H} 4$ and support the reasoning that the higher the level of customer trust, the higher the level of customer loyalty $(\beta=0.508 ; \mathrm{t}=7.011)$. Therefore, $\mathrm{H} 4$ is supported. Finally, the results depicted in Table 4 and Figure 2 are also consistent with $\mathrm{H} 5$ and support the proposition that the more customers are intimate with a brand, the more they are loyal to it $(\beta=0.232, \mathrm{t}=2.392)$.

\section{CONCLUSION}

The purpose of this study was to investigate the influence of service quality, customer satisfaction, customer trust, and customer intimacy on their loyalty. In particular, five hypotheses were postulated. To test the proposed hypotheses, data were collected from Gauteng Province in South Africa. The empirical result supported all the five posited research hypotheses in a significant way.

Important to note in the study findings is the fact that service quality and customer satisfaction have influence on customer loyalty through customer trust and customer intimacy. This implies that service quality and customer satisfaction have stronger influence on customer loyalty when they first trigger the customer's trust and intimacy.

\section{IMPLICATIONS OF THE STUDY}

While there is an increased recognition of customer loyalty as a critical aspect of today's competitive business environment, the extant literature is replete with empirical evidence suggesting that service quality, customer satisfaction, customer trust, and customer intimacy are related constructs of customer loyalty. However, the current study was set to depart from this long held conventional wisdom and attempts to investigate the causal relationships between these constructs in service provision in the mobile phone industry. In particular, a successful attempt was made in this study to service quality, customer satisfaction, customer trust, and customer intimacy as predictors of customer loyalty. In addition, the current study investigated this contentious issues in an often most neglected research context - the African setting. Therefore, the findings of this empirical study are expected to provide fruitful new insights and implications to both academicians and mobile phone practitioners across the globe.

On the academic side, this study makes a significant contribution to the customer service and retailing literature by exploring the impact of service quality, customer satisfaction, customer trust, and customer intimacy on customer loyalty in the African context. In particular, the current study findings provide tentative support to the proposition that service quality, customer satisfaction, customer trust, and customer intimacy should be recognized as antecedents and tools that precipitate customer loyalty in the mobile phone industry.

On the practitioners' side, important influential roles of service quality, customers' satisfaction and their trust and intimacy, and, consequently, their loyalty to mobile phone brands in an African context, are highlighted. Therefore, this study for instance submits that mobile phone operators seeking to find ways to attract and retain customers should begin to consider this behaviour not only as the interplay of service quality, customer satisfaction, customer trust, customer intimacy, and customer loyalty, but rather one that is precipitated by the quality of service provided, the extent to which customers are satisfied, and then develops to trust and intimacy before it manifests itself in the form of loyalty to the brand. 


\section{LIMITATIONS AND FUTURE RESEARCH}

Although this study makes significant contributions to both academia and practice, it was limited in some ways; therefore, some future research avenues are suggested: 1) the data were gathered from Gauteng Province of South Africa and the sample size of 151 is relatively small. Perhaps the results would be more informative if the sample size were larger and data were gathered from the other eight provinces of the country. Therefore, future studies may be conducted by using data from other provinces in South Africa. 2) Perhaps, too, future studies should not be limited to South Africa, but rather consider extending this research to other African countries, such as Zimbabwe, for results comparison. Future studies can also extend the current study by studying the relationships in the current conceptual model in other sectors of the economy. Above and beyond, this will immensely contribute new knowledge to the existing body of consumer purchase behaviour in the mobile phone industry literature in the African setting - a research context which happens to be neglected in academics.

\section{AUTHOR INFORMATION}

Dr. Richard Chinomona is a Senior Lecturer and Facilitator of Research Methodology at Vaal University of Technology, Faculty of Management Sciences - Department of Logistics. He is a holder of six degrees and has published extensively in various international peer-reviewed journals. E-mail: rchinos@hotmail.com (Corresponding author)

Dr. Maxwell Sandada is a Lecturer in the Faculty of Management at Vaal University of Technology, in South Africa. He has published several accredited articles in referred journals and has presented papers international conferences all over the world He holds a Doctor of Technology Degree in Business from Vaal University of Technology, South Africa. E-mail: maxwells@ vut.ac.za

\section{REFERENCES}

1. Aydin, S. and Özer. 2005. The Analysis of antecedents of customer loyalty in the Turkish mobile telecommunication market, European Journal of Marketing. 39(8/9): 910-925.

2. Beatty, R.W. \& Huseld, M.A. \& Schneier, C.E. 2003. New HR Metrics: Scoring on the Business Scorecard. Organisational Dynamics, 32(2): 107-121.

3. Beerli, A., Martin, J.D. \& Quintana, A. 2004. A Model of Customer Loyalty in the Retail Banking Market. European Journal of Marketing, 38(1/2): 253-275.

4. Boshoff, C. \& du Plessis, F. 2009. Services Marketing: A Contemporary Approach. Juta and Company Ltd. Cape Town.

5. Bugel, M.S., Verhoel, P.C. \& Buunk, A.P. 2011. Customer Intimacy and Commitment to relationships with Firms in Five Different Sectors: Preliminary Evidence. Journal of Retailing and Consumer Services, 18: 247-258.

6. Chang, J.C. 2006. Customer Satisfaction with Tour Leaders' Performance: A Study of Taiwan's Package Tours. Asia Pacific Journal of Tourism Research, 11(1): 97-116.

7. Cheng, C.C., Chiu, S.I., Hu, H.Y. \& Chang, Y.Y. 2011. A study on Exploring the Relationship Between Customer and Loyalty in the Fast Food Industry: With Relationship Inertia as a Mediator. African Journal of Business Management, 5(13): 5118-5126.

8. Chin WW \& Newsted PR 1999. Structural equation modeling analysis with small samples using partial least squares. In Rick Hoyle (ed). Statistical Strategies for Small Sample Research. Thousand Oaks, CA: Sage. pp. 307-341.

9. Chin WW 1998. Issues and opinion on structural equation modelling, MIS Quarterly, 22(1), 7-16.

10. Chinomona, R \& Surujlal, J. (2012). The influence of student internship work experience on their selfimprovement and professionalism in Sport Management, African Journal for Physical, Health Education, Recreation and Dance (AJPHERD), 18: 4(2), 885-899.

11. Choi, C. \& Sheel, A. 2012. Assessing the Relationship Between Waiting Services and Customer Satisfaction in Family Restaurants. Journal of Quality Assurance in Hospitality \& Tourism, 13: 24-36.

12. Dabholkar, P.A. \& Sheng, X. 2012. Consumer Participation in Using Online Recommendation Agents: Effects on Satisfaction, Trust, and Purchase Intentions. The Service Indusries Journal, 32(9): 1433-1449. 
13. Deng, Z., Lu, Y., Wei, K, K. \& Zhang, J. 2010. Understanding Customers Satisfaction and Loyalty: An empirical study of mobile Instant messages in China. International Journal of Information Management, 30(2010): 289-300.

14. Hamadi, C. 2010. The Impact of Quality of Online Banking on Customer Commitment. Communications of the IBIMA, 2010: 1-8.

15. Han, H. \& Ryu, K. 2009. The Roles of Physical Environment, Price Perception, and Customer Satisfaction in Determining Customer Loyalty in the Restaurant Industry. Journal of Hospitality \& Tourism Research. 33: 487-510.

16. Hong, I.B. \& Cho, H. 2011. The Impact of Consumer Trust on Attitudinal Loyalty and Purchase Intention in B2C E-marketplace: Intermediary Trust vs Seller Trust. International Journal of Information Management, 31(2011): 469-479.

17. Huddleston, P., Whipple, J., Mattick, R.N. \& Lee, S.J. 2009. Customer Satisfaction in Food Retailing: Comparing specialty and conventional grocery stores. International Journal of Retail and Distribution Management, 37(1): 63-80.

18. Hu, H.Y., Chiu, S.I., Cheng, C.C. \& Hsieh, Y.F. 2010. A Study of Investigating Patient Satisfaction of Medical Centres Using Taiwan Customer Satisfaction Index in Taiwan. African Journal of Business Management, 4(14): 3207-3216.

19. Hu, H.H., Kandampully, J. \& Juwaheer, T.D. 2009. Relationships and Impacts of Service Quality, Customer Satisfaction, and Image: An Empirical Study. The Service Industry Journal, 29(2): 111-125.

20. Hwang, J. \& Zhang, J. 2010. Factors Influencing Customer Satisfaction or Dissatisfaction in the Restaurant Business Using AnswerTree Methodology. Journal of Quality Assurance in Hospitality and Tourism, 11: 93-110.

21. Kang, S.S., Okamoto, N. \& Donovan, H.A. 2004. Service Quality and its Effect on Customer Satisfaction and Customer Behavioural Intentions: Hotel and Ryokan Guests in Japan. Asia Pacific Journal of Tourism Research, 9(2): 2004.

22. Katibi, A.A., Ismail, H. \& Thyagarajan, V. What Drives Customer Loyalty: An Analysis from the Telecommunications Industry. Journal of Targeting, Management and Analysis for Marketing, 11(1): 3444.

23. Kim, M.K., Park, M.C. \& Jeong, D.H. 2004. The effects of Customer Satisfaction and Switching Barrier on Customer in Korean Mobile Telecommunication Services. Telecommunications Policy, 28: 145-159.

24. Kuo, Y.F., Wu, C.M. \& Deng, W. J. 2009. The Relationship Among Service Quality, Perceived Value, Customer Satisfaction, and Post-Purchase Intention in Mobile Value -Added Service. Computers in Human Behaviour, 25(4): 887-896.

25. Lai, F., Griffin, M. \& Babin, B.J. 2009. How Quality, Value, Image, and Satisfaction Create Loyalty at a Chinese Telecom. Journal of Business Research, 62: 980-986.

26. Lee, H.S. 2010. Factors Influencing Customer Loyalty of Mobile Service: Empirical Evidence from Koreans. Journal of International Banking and Commerce, 15(2): 1-14.

27. Lee, J.J., Kyle, G. \& Sctt, D. 2012. The mediating effect of Place Attachment between Festival Satisfaction and Loyalty to the Festival Hosing Destination. Journal of Travel Research, 51(6): 754-767.

28. Lee, T.H. \& Shen, Y.1. 2013. The Influence of Leisure Involvement and Place Attachment on Destination Loyalty: Evidence From Recreationists Walking their Dogs in Urban Parks. Journal of Environmental Psychology, 33: 76-85.

29. Li, M. 2009. The Customer Value Strategy in the Competitiveness of Companies. International Journal of Business and Management, 4(2): 136-142.

30. Lin, H.H. \& Wang, Y.S. 2005. An Examination of the Determinants of Customer Loyalty in Mobile Commerce Contexts. Information and Management, 43: 271-282.

31. Liu, C-T., Guo, Y.M \& Lee, C-H. (2011). The effects of relationship quality and switching barriers on customer loyalty, International Journal of Information Management, 31(2) 71-79.

32. Mai, L.W. \& Ness, M.R. 2006. A Structural Equation Model of Customer Satisfaction and Future Purchase of Mail-Order Speciality Food. International Journal of Business Science and Applied Management, 1(1): $1-14$.

33. Meng, S.M., Liang, G.S. \& Yang, S.H. 2011. The Relationships of Cruise Image, Perceived Value, Satisfaction, and Post-Purchase behavioural Intention on Taiwanese Tourists. African Journal of Business Management, 5(1): 19-29. 
34. Olaru, D., \& Purchase, S. \& Peterson, N. 2008. From Customer Value to Repurchase Intentions and Recommendations. Journal of Business and Industrial Marketing, 23(8): 558-565.

35. Ou, C.X. \& Sia, C.L. 2003. Customer Loyalty Strategy in the Internet Era. $7^{\text {th }}$ Pacific Asia Conference on Information Systems, 10-13 July, Adelaide, South Australia.

36. Pontiskoski, E \& Asakawa, K. 2009. Overcoming Barriers to Open Innovation at Apple, Nintendo and Nokia. World Academy of Science, Engineering and Technology, 53: 372-377.

37. Reiman, M., Schilke, O. \& Thomas, J.S. 2010. Toward an Understanding of Industry Commoditization: Its Nature and Role in Evolving Market Competition. International Journal of Research in Marketing, 27: 188-197.

38. Ringle CM, Wende S \& Will A 2005. SmartPLS 2.0 M3. Available at http://www.smartpls.de. Accessed 23/03/2013.

39. Sandada, M. 2013. Strategic Planning and its Relationship with the Performance of Small and Medium sized enterprises in Gauteng. Unpublished Doctoral Dissertation. Vaal University of Technology, Johannesburg. South Africa.

40. Shemwell, J.D., Yavas, U \& Bilgin, Z. (1998) "Customer-service provider relationships: an empirical test of a model of service quality, satisfaction and relationship-oriented outcomes", International Journal of Service Industry Management, 9(2), 155 - 168.

41. Sivadas, E. Prewitt, J.L.B. 2000. An Examination of the Relationship Between Service Quality, Customer Quality, Customer Satisfaction, and Store Loyalty. International Journal of Retail and Distribution Management, 28(2): 73-82.

42. Stahl, H.K., Martzler, K. \& Hinterhuber, H.H. 2003. Linking Customer Lifetime Value with Shareholder Value. Industrial Marketing Management, 32: 267-279.

43. Siddiqi, K.O. (2011), Interrelations Between Service Quality Attributes, Customer Satisfaction and Customer Loyalty in the Retail Banking Sector in Bangladesh. International Journal of Business and Management, 6(3): 12-37.

44. Tenenhaus M, Vinzi VE, Chatelin YM, \& Lauro C 2005. PLS path modeling. Computational Statistics \& Data Analysis, 48(1), 159-205.

45. Wallace, D.W., Giese, J.L. \& Johnson, J.L. 2004. Customer Retailer Loyalty in the Context of Multiple Channel Strategies. Journal of Retailing, 80: 249-263.

46. Wetzels M, Odekerken-Schröder G \& Van Oppen C. 2009. Using PLS path modeling for assessing hierarchical construct models: guidelines and empirical illustration. Management Information Systems Quarterly, 33(1), 177-195.

47. Wong, A. \& Sohal, A. 2003. Service Quality and Customer Loyalty Perspectives on Two Levels of Retail Relationships. Journal of Services Marketing, 17(5): 495-513. 


\section{APPENDIX}

\section{Measurement Instruments}

Service Quality

Overall, I'd say the quality of my interaction with the provider's employees is excellent.

I would say that the quality of my interaction with the provider's employees is high.

I always have an excellent experience when I interact with my service provider.

I feel good about what my service provider provides to its customers.

Satisfaction

I am satisfied with my mobile service provider.

I am satisfied with the relationship I have with my service provider.

Overall I am satisfied with the service that I receive from my mobile service provider.

I have experienced some sort of problems with my service provider, but the problems are always fixed speedily.

I have a reliable mobile service provider.

Trust

My mobile service provider can be relied upon to keep promises.

My mobile service provider is trustworthy.

I have full confidence in my mobile service provider.

Intimacy

My mobile service provider cares for its customers.

I like to communicate with my mobile service provider.

I feel intimacy toward my mobile service provider.

Loyalty

I intend to stay with the current service provider for a long period.

I intend to recommend it to friends and family.

Even if other service providers offer better alternatives I will stay with my service provider. 